\title{
Effects of Microfinance Intervention on Multiple and Non-multiple Financing Clients: A Case of Gandaki Province of Nepal
}

\author{
Bharat Ram Dhungana, $\mathrm{PhD}^{*}$ \\ Ramkrishna Chapagain $^{* *}$ \\ Deepesh Ranabhat ${ }^{* * *}$
}

DOI: https://doi.org/10.3126/jnbs.v13i1.34703

Received on 2 May 2020

Accepted on 20 November 2020

\begin{abstract}
The objective of this study is to examine the effects of microfinance intervention on multiple and non-multiple borrowings clients in the Gandaki province of Nepal. Further, the study aims to explore the reasons for multiple borrowings and the impact of microfinance intervention on micro-enterprise creation, total investment, profit per month, income, and saving. The research is based on primary sources of data and confined to Muktinath Biikas Bank Limited (MBBL). Microfinance clients involving MBBL for the last five or more years are the respondents, and 311 $M F$ clients were randomly selected from 10 branches of $M B B L$. Both descriptive and inferential statistics have been applied to find out the effects of microfinance intervention. The key reasons behind multiple financing are forced by friends, the presence of other MFIs, insufficient loan, meeting domestic requirements, repaying other MFIs loan, lending to others at high interest, and repaying a high-interest loan. There are significant differences between multiple and non-multiple financing clients in terms of micro-enterprise creation, total investment, profit per month, and saving. The result shows that non-multiple financing clients are more likely to earn more profit, create new business, and have the potential for large-scale investment. The mean score shows that non-multiple financing clients are saving more than multiple financing clients, indicating more commitment to saving for future funds requirement to expand the business. At last, the study concluded that the performance of non-multiple financing clients is significantly better than multiple financing clients. Since multiple financing creates problems if it is not controlled properly, so microfinance institutions (MFIs) and regulatory authorities should discourage multiple borrowing practices through proper regulation, adequate supply of loans, and its productive orientation.
\end{abstract}

Keywords: Microfinance intervention, multiple financing, non-multiple financing

* Dr. Dhungana is an Associate Professor at School of Business, Pokhara University, Nepal.

${ }^{* *}$ Mr. Chapagain is an Assistant Professor at School of Business, Pokhara University, Nepal.

${ }^{* * *}$ Mr. Ranabhat is an Assistant Professor at School of Business Pokhara University, Nepal.

Corresponding author: Ramkrishna Chapagain. Email: ramkrishnachapagain@gmail.com 


\section{INTRODUCTION}

Microfinance is a tool of financial inclusion that provides financial services to people who have no access to formal financial institutions such as commercial banks. MFIs provide a wide range of financial services generally micro-savings, micro-credit, micro-insurance, and payment services. In addition to financial intermediation, many MFIs provide social intermediation services such as group formation, financial literacy programs, and capabilities development among members of a group (Ledgerwood, 1999). MFIs apply a unique credit delivery mechanism that provides loans to the marginalized and disadvantaged people under a collateral-free group-based lending system. MF is taken as an effective tool for financial inclusion and poverty reduction in developing countries like Nepal. As a result, MF has become a significant part of development finance to address poverty reduction, employment creation, and socio-economic transformation of the people. MF is a way of reaching the poor and marginalized people.

Large numbers of people are still depending on the informal lending system in the country especially in hilly and rural areas due to poor financial inclusion. The status of financial inclusion in Nepal is not satisfactory and more than half of the adult population (55.0 percent) are still unbanked (World Bank, 2017). Unless financial inclusion is made effective, most people will be deprived of formal financial services. However, building an inclusive financial system is a challenging task that requires a high degree of effort and commitment. The government should provide enough supports to develop financial infrastructure, sound MF policies, strengthening the regulatory authority, and inclusive economic growth that will help to build-up an inclusive financial environment in the nation.

Microfinance is a significant way of connecting the unbanked population into the mainstream through a collateral-free group-based lending system. The number of MFIs has been providing MF services in Nepal, however, the people living in the rural part of Nepal is unable to get formal financial services and is still depending on the informal lending system. Most of the banking institutions are concentrated in urban and suburban areas. Inadequate basic infrastructure is the main problem in the hilly and mountainous region that has discouraged an expansion of microfinance services to the rural remote areas. Unless the marginalized and disadvantaged people will get formal financial services, financial inclusion remains poor. There is a need to enhance the social and financial performance of the MF industry to promote an inclusive financial environment in the nation.

Multiple borrowing refers to the multiple memberships of an individual or a household (Faruqee \& Khalily, 2011; Lahkar \& Pingali, 2014; Lutzenkirchen \& Weistroffer, 2012). Generally, borrowing from different MFIs and investing the finances together in a productive business may enhance the social wellbeing of the borrowers (Krishnaswamy, 2007). However, it may have a disastrous effect if borrowers keep accumulating debt with little or no ability to repay. Multiple borrowing is sometimes synonymous with over-indebtedness when monthly loan repayments exceed 50 percent of income (Maurer \& Pytkowska, 2010). 
Over-indebtedness has been defined as a situation whereby a borrower fails to make repayments, which in the long run increases the borrower's financial vulnerabilities (Schicks, 2014). Many Indian farmers from Andhra Pradesh (one of the areas most penetrated by the microfinance industry) committed suicide because they were unable to repay multiple loans taken from MFIs (Levin, 2012). Multiple borrowing may have a direct impact on such incidents (Ashta, Khan, \& Otto, 2015); however, its severity and actual effect are still largely unknown. Multiple borrowing and the causes of multiple borrowing have become a topic of interest among academicians in microfinance.

Islam (2019) examined the impact of multiple borrowing on the living standard of the borrowers. The result shows that there is no significant difference in gross income between the groups of borrowers borrowing from a single source and borrowing from multiple sources. But, in the case of living expenses, savings, and the number of non-land assets, there is a significant difference between the groups. Borrowers who borrow from a single source can spend more on quality life than those who borrow from multiple sources. The borrowers borrowing from a single source have a significantly higher amount of savings and non-land assets than those who borrow from multiple sources. Policymakers should make policies in a way so that the borrowers can get a sufficient amount of loans from one source and they are encouraged to avoid loans from multiple sources that impose a higher level of loan transaction costs and repayment burden.

Debnath and Roy (2018) researched predicting multiple-borrowing defaults among microfinance clients. To control over-indebtedness that often leads to capacity failure, the Reserve Bank of India recently issued directives for MFIs to restrict multiple loans to borrowers. These institutions are also required to regularly share their current borrowers' loan records with a Credit Information Company. The study finds that ex-post loan record verification is inefficient and inadequate considering the socio-economic and informational asymmetries in micro-credit markets. Instead, household characteristics can predict multipleborrowing behaviour. The empirical analysis shows that this is true to some extent and dwell on policy implications.

Dhungana, Singh, Acharya, Gautam, and Paudyal (2016) conducted a community-based cross-sectional study in four districts of western Nepal. A total of 500 microfinance clients representing different ethnic groups (upper caste, aadibasi and janajati, and dalit) were selected by using systemic random sampling. Health awareness and practices among different ethnic groups were compared by logistic regression after adjustment for age, level of education, sex of household heads, occupation, and place of residence. The study finds a positive effect of microfinance on health awareness and practices among different ethnic groups of Nepal. This finding supports further implementation and evaluation of equity-based microfinance to improve the health and economic conditions of Nepalese people. 
Tilakaratna and Hulme (2015) found an increment of multiple borrowing in the microfinance sector concerning Sri Lanka, while many microfinance institutions have experienced high levels of borrower turnover, deteriorating portfolio quality, and weak financial performance. This has raised concerns about the microfinance sector. However, the debt levels for most borrowers remain at moderate levels, but several mitigating factors such as mobilization of borrower savings by MFIs, wide use of pawning among clients, and a reduction in donor funds to the sector. The high and rising levels of multiple borrowing among MFI clients suggest the need for greater client protection, more effective monitoring and regulation, credit information sharing among MFIs, and strengthening the performance of MFIs.

Mpogole, Mdaungulu, Mlasu, and Lubawa (2012) explored the prevalence of multiple borrowing at Iringa in Tanzania was very high. Over 70 percent of microfinance clients had at least two loans from different MFIs at the same time. Besides, about 16 percent had also borrowed from individual lenders. Major reasons for multiple borrowing were insufficient loans from MFIs, loan recycling, and family obligations. Over 70 percent of the respondents had problems in loan repayment because of multiple pending loans. The study finds that the education level and the number of dependents of the respondent significantly influenced the number of loan contracts.

The evidence from countries such as India, Nicaragua, Bosnia, Herzegovina, and Morocco shows that multiple borrowing in the microfinance sector led to increased debt levels among MFI clients, causing repayment crises in these countries (Chen, Rasmussen, \& Reille, 2010; Microfinance Focus, 2011). The experience of Andhra Pradesh may be leading to a partial reversal in the outlook for microfinance. Doubts about whether microfinance does benefit the poor (Bateman, 2010; Roodman, 2012) and concerns over multiple lending, multiple borrowing, and client over-indebtedness. Policymakers and donors should focus on a series of new concepts such as 'responsible finance' and 'client protection' (Center for Financial Inclusion, 2011).

From the above literature, it is obvious that multiple borrowing is a serious problem in many countries. Nepalese MFIs are facing multiple borrowing complications such as overindebtedness and default cases. In this study, the effects of microfinance intervention on multiple and non-multiple borrowings clients with reference to MBBL has been examined. Further, the study aims to explore the reasons for multiple borrowings and the impact of microfinance intervention on micro-enterprise creation, total investment, profit per month, income, and saving patterns of MF clients.

\section{DATA AND METHODS}

The research follows the quantitative approach based on primary sources of data collected through structured questionnaires. The study has been confined to the Gandaki province of Nepal. Out of the eleven districts, MBBL has provided MF access to nine 
districts and five districts were randomly selected for the study. The MF clients were randomly selected from each center of MBBL. The field survey is targeting multiple borrowing and non-multiple borrowing clients, both representing the municipality and rural municipality. Microfinance clients, who are involved in MBBL for the last five or more years, are the respondents and $311 \mathrm{MF}$ clients were randomly selected from 10 branches. The sample is justifiable because at a 92 percent confidence interval and 5 percent margin of error required sample size is 306 under an infinite population (Godden, 2004). Both descriptive, such as frequency, percentage, and mean, and inferential statistics, such as chi-square test independent sample t-test, and logistic regression, have been applied to find out the effects of microfinance intervention.

For the reliability analysis, Cronbach's alpha has been calculated. Its value is 0.76 , which is greater than 0.6. Further, for the validity of the study, questionnaires were constructed based on the past literature and consulted with experts for correction. Besides, pilot testing was performed before finally administrating the questionnaire.

\section{RESULTS AND DISCUSSION}

\subsection{Descriptive Analysis}

The descriptive analysis has been presented in the form of demographic profile, microfinance related information of clients and others.

\subsubsection{Demographic Profile of Respondents}

The demographic characteristics for the individual respondents have been characterized through the household head, address, age structure, ethnic group, marital status, educational status, and occupation. These variables were recorded and analyzed in percentiles using SPSS. The summary of the demographic characteristics of respondents has been presented in Table 1.

It is obvious from Table 1 that 54.0 percent of household heads are female and 46 percent of respondents have a male household head. Many respondents (42.4 percent) are Brahaman, Chhetri, and others in terms of the ethnic group whereas the remaining are Janajati and Adhibasi (32.8 percent) and Dalit (24.8 percent). Likewise, in terms of educational status, 21.5 percent are illiterate, 44.7 percent have primary level education, 28.0 percent have a secondary level and 5.8 percent have above secondary level education. Furthermore, respondents of age between 31 and 40 occupied a large area of pie (39.5) percent. Further, 54 percent of respondents have been involving in agriculture followed by business by 41.8 percent. 
Table 1

Respondents' Demographic Profile

\begin{tabular}{clcc}
\hline Demographic variables & Categories & Frequency & Percent \\
\hline \multirow{2}{*}{ Household head } & Male & 143 & 46.0 \\
& Female & 168 & 54.0 \\
\hline \multirow{2}{*}{ Age structure } & $20-30$ & 59 & 19.0 \\
(years) & $31-40$ & 123 & 39.5 \\
& $41-50$ & 79 & 25.4 \\
& More than 50 & 50 & 16.1 \\
\hline \multirow{3}{*}{ Ethnic group } & Dalit & 77 & 24.8 \\
& Janajati and Adhibasi & 102 & 32.8 \\
& Others* & 132 & 42.4 \\
\hline \multirow{2}{*}{ Marital status } & Married & 282 & 90.7 \\
& Divorced/separated & 3 & 1.0 \\
& Widow & 26 & 8.4 \\
\hline \multirow{2}{*}{ Education } & Illiterate & 67 & 21.5 \\
& Primary education & 139 & 44.7 \\
& Secondary education & 87 & 28.0 \\
& Above the secondary & 18 & 5.8 \\
\hline \multirow{2}{*}{ Occupation } & level & 6 & 1.9 \\
& Job & 130 & 41.8 \\
& Business & 168 & 54.0 \\
& Agriculture/Livestock & 711 & 2.3 \\
\hline & Others & & 100 \\
\hline & & & 6 \\
\hline
\end{tabular}

Note. *Others include upper-caste such as Brahaman, Chhetri, and so on.

Source: Field survey, 2019.

\subsubsection{Multiple MFIs Account}

The clients, who have been involved in multiple financing or not, have been identified with the help of dichotomous variables. The multiple MFIs account of the clients has been presented in Table 2 .

It is obvious from Table 2 that most of the respondents (59.5 percent) reported that they have multiple MFIs account in various MFIs. Multiple financing problems are one of the big issues in the field of the microfinance sector. 
Table 2

Multiple MFIs Account

\begin{tabular}{ccc}
\hline Multiple MFIs account & Frequency & Percent \\
\hline Yes & 185 & 59.5 \\
No & 126 & 40.5 \\
\hline Total & 311 & 100 \\
\hline
\end{tabular}

Source: Field survey, 2019.

\subsubsection{Reasons behind Multiple Financing}

The reasons for multiple financing have been presented in Table 3.

Table 3

Reasons behind Multiple Financing

\begin{tabular}{lcc}
\hline Reasons(Including multiple reasons) & Frequenc & Percent \\
\hline Insufficient loan & y & 33.5 \\
Presence of other MFIs and loan request & 62 & 60.0 \\
To repay other MFIs loan & 111 & 19.5 \\
To meet other requirements(marriage, health, education, etc.) & 36 & 23.2 \\
Repayment of the high-interest loan (such as money lenders) & 4 & 2.2 \\
Lending to others at high interest & 16 & 8.7 \\
Forced by friends & 120 & 64.9 \\
\hline Total & 185 & 100 \\
\hline
\end{tabular}

Source: Field survey, 2019.

A large portion of respondents (64.9 percent) reported that the main reason behind multiple financing was forced by friends and the presence of other MFIs and loan request (60.0 percent). Similarly, 33.5 percent reported insufficient loan, 23.2 percent reported to meet other requirements (such as marriage, health, education), 19.5 percent reported to repay other MFIs loan, 8.7 percent reported lending to others at high interest and 2.2 percent reported repayment of the high-interest loan was the reasons behind multiple financing. Unhealthy competition among the MFIs should be discouraged in the MF sectors.

\subsection{Inferential Statistics}

\subsubsection{Micro-enterprises Creation}

Table 4 presents the chi-square test between types of clients with micro-enterprises creation. 
Table 4

Micro-enterprises Creation

\begin{tabular}{|c|c|c|c|c|}
\hline \multirow{2}{*}{ Micro-enterprises characteristics } & \multicolumn{2}{|c|}{ Type of clients } & \multirow{2}{*}{$\begin{array}{c}\text { Chi- } \\
\text { square }\end{array}$} & \multirow{2}{*}{ Sig } \\
\hline & Multiple & Non- multiple & & \\
\hline \multicolumn{5}{|l|}{ Creation of micro-enterprises } \\
\hline Yes & 63 & 92 & \multirow{2}{*}{45.51} & \multirow{2}{*}{$0.0001 * * *$} \\
\hline No & 122 & 34 & & \\
\hline \multicolumn{5}{|l|}{ Total investment (in NRS) } \\
\hline Below 100,000 & 15 & 23 & \multirow{5}{*}{17.38} & \multirow{5}{*}{$0.002 * * *$} \\
\hline 100,001 to 300,000 & 33 & 36 & & \\
\hline 300,001 to 500,000 & 34 & 23 & & \\
\hline 500,001 to $1,000,000$ & 55 & 21 & & \\
\hline Above $1,000,000$ & 48 & 23 & & \\
\hline \multicolumn{5}{|l|}{ Profit per month(in NRS) } \\
\hline Below 20,000 & 58 & 14 & \multirow{5}{*}{48.83} & \multirow{5}{*}{$0.001 * * *$} \\
\hline 20,001 to 30,000 & 59 & 22 & & \\
\hline 30,001 to 40,000 & 32 & 22 & & \\
\hline 40,001 to 50,000 & 21 & 51 & & \\
\hline Above 50,000 & 15 & 17 & & \\
\hline \multicolumn{5}{|l|}{ Increase in income level (in NRS) } \\
\hline Up to 10,000 & 91 & 64 & \multirow{6}{*}{14.289} & \multirow{6}{*}{$0.014 * *$} \\
\hline 10,001 to 20,000 & 22 & 6 & & \\
\hline 20,001 to 30,000 & 5 & 2 & & \\
\hline 30,001 to 40,000 & 1 & 4 & & \\
\hline 40,001 to 50,000 & 0 & 3 & & \\
\hline Above 50,000 & 1 & 3 & & \\
\hline
\end{tabular}

Note. The asterisk signs $(* * *)$, and $(* *)$ indicate that the results are significant at 1 percent and 5 percent level respectively. NRS denotes Nepalese rupees and $1 \$=$ NRS 120.05 as of $24^{\text {th }}$ August 2020.

Source: Field survey, 2019.

There is a significant association between types of clients and an increase in income level, types of clients, and creation of micro-enterprise, types of clients, and total investment and types of clients and profit per month. The result shows that non-multiple financing earned more profit, created more business, and belongs more to the high-income category. This indicates that, in the future, there may arise problems because of multiple financing and it will create economic unrest and crisis as it happened in Andra Pradesh of India. 


\subsubsection{Saving}

The saving has been in the form of compulsory and voluntary. Table 5 shows the types of clients and their savings.

Table 5

Types of Clients and their Saving Amount

\begin{tabular}{lccc}
\hline \multicolumn{2}{c}{ Types of clients } \\
\cline { 1 - 2 } \cline { 1 - 2 } Saving (in NRS) & Multiple financing & Non-multiple financing & \\
\cline { 1 - 3 } Compulsory & Mean & Mean & $0.02^{* *}$ \\
Voluntary & 297.89 & 350.04 & 0.23 \\
Total & 642.38 & 548.10 & $0.04^{* *}$ \\
\hline
\end{tabular}

Note. The asterisk sign $(* *)$ refers that the results are significant at 5 percent level. NRS denotes

Nepalese Rupees and $1 \$=$ NRS 120.05 as per $24^{\text {th }}$ August 2020.

Source: Field survey, 2019.

The mean score shows that non-multiple financing clients are saving more than multiple financing clients. The independent-sample t-test shows that there is a significant mean difference between non-multiple financing clients and multiple financing clients in terms of compulsory and total saving. It indicates that non-multiple clients are engaged in saving. In economic theory, when clients save more today, they have the chance to invest in a more productive sector in the future.

\subsubsection{Purpose of Taking Loan}

Table 6 shows the result of the purpose of taking loans of both multiple financing and non-multiple financing clients.

Table 6

Purpose of Taking Loan

\begin{tabular}{|c|c|c|c|c|}
\hline \multirow{2}{*}{ Objectives of taking loan } & \multicolumn{2}{|c|}{ Types of clients } & \multirow{2}{*}{$\begin{array}{c}\text { Chi-square } \\
\text { value }\end{array}$} & \multirow{2}{*}{ p-value } \\
\hline & Multiple & Non-multiple & & \\
\hline Micro business-retail/Service & 45 & 60 & 38.71 & $0.0001 * * *$ \\
\hline Micro enterprises & 7 & 13 & & \\
\hline Agriculture & 25 & 16 & & \\
\hline Lending to other & 82 & 19 & & \\
\hline Repayment of other loans & 18 & 12 & & \\
\hline Others & 8 & 2 & & \\
\hline
\end{tabular}

Note. The asterisk sign $(* * *)$ refers that the results are significant at 1 percent level.

Source: Field survey, 2019. 
Table 6 clearly shows that most of the multiple financing clients take the loan to use for unproductive sectors such as lending to other people whereas non-multiple financing clients used loans for the creation of new business and micro-enterprises. The chi-square pvalue shows that there is an association between the purpose of taking loans and types of clients. Most of the multiple financing clients used the loan to lend others that shows an unproductive investment of loan, but non-multiple financing clients used the loan for the creation of new business and micro-enterprises.

\subsubsection{Performance Effectiveness of Multiple Financing and Non-Multiple Financing Clients}

Table 7 shows the results of binary logistic regression. Here, clients involving multiple financing and not involving in multiple financing is the response variable. The level of investment, level of profit, creation of business and total saving of the clients are predictors.

Table 7

Performance Effectiveness of Multiple Financing and Non-Multiple Financing Clients

\begin{tabular}{lccc}
\hline Variables & $\begin{array}{l}\text { Beta } \\
\text { coefficient }\end{array}$ & Sig. value & Odds ratio \\
\hline $\begin{array}{l}\text { Investment (in NRS): } \\
\text { Below 100,000 }\end{array}$ & -2.1 & $0.0001^{* * *}$ & 0.122 \\
100,001 to 300,000 & -1.24 & $0.018^{* * *}$ & 0.289 \\
300,001 to 500,000 & -0.504 & 0.332 & 0.604 \\
500,001 to 1000,000 & 1.025 & $0.048^{* *}$ & 2.786 \\
Above1000,000 & & & \\
Profit (in NRS): & & 0 & \\
Below 20,000 & 2.073 & $0.0001^{* * *}$ & 7.95 \\
20,001 to 30,000 & 1.866 & $0.0001^{* * *}$ & 6.465 \\
30,001 to 40,000 & 1.153 & $0.014^{* *}$ & 3.168 \\
40,001 to 50,000 & 0.88 & $0.059^{*}$ & 2.412 \\
Above 50,000 & 1.864 & $0.0001^{* * *}$ & 6.447 \\
Creation of business & 0.0001 & $0.029 * *$ & 1 \\
Saving & -2.384 & 0 & 0.092 \\
Constant & & & \\
\hline
\end{tabular}

Note. (1) The asterisk sign $(* * *),(* *)$ and $(*)$ refer that the results are significant at 1,5 and 10 percent level respectively. (2) NRS denotes Nepalese Rupees and $1 \$=$ NRS 120.05 as per $24^{\text {th }}$ August 2020. (3) Nagelkerke R Square $=0.439$; Sensitivity $=7$ 9.5; Specificity $=67.5$.

Source: Field survey, 2019. 
Taking clients with multiple financing as a reference group the result of logistic regression shows that clients of non-multiple financing are less likely to invest up to NRs.1000, 000. But they are more likely to invest more than NRs.1, 000,000 than multiple financing clients by 2.786 times. This shows they have high investment potential. Likewise, clients of non-multiple financing have more chances to earn a profit than clients of multiple financing which is justified by the above odds ratio and their corresponding $p$-value. Better investment potential and a greater chance of earning potential indicate that non-multiple financing clients have a good potential to run the business than multiple financing clients. Clients of non-multiple financing are 6.44 times more likely to create a new business than multiple financing. Moreover, saving is a significant factor for opening accounts in microfinance. The clients of multiple and non-multiple financing have equally likely to increase. The sensitivity and specificity ratio and R-square show the model is well fitted.

\section{CONCLUSION AND SUGGESTIONS}

The study finds that most of the respondents reported multiple MFIs accounts in various MFIs. Multiple financing problem is one of the big issues in the field of the microfinance sector. The perception of a large portion of respondents behind multiple financing is forced by friends and the presence of other MFIs for loan requests. Likewise, insufficient loan, meeting other requirements (such as marriage, health, education), repaying other MFIs loan, lending to others at high interest, and repaying the high-interest loan are the key reasons behind multiple financing.

There is a significant association between types of clients and an increase in income level, types of clients, and creation of micro-enterprise, types of clients, and total investment and types of clients and profit per month. The result shows that non-multiple financing has more profit, created more business, and belongs more to the high-income category. Clients of non-multiple financing are 6.44 times more likely to create a new business than multiple financing. The mean score shows that non-multiple financing clients are saving more than multiple financing clients. Saving is a significant factor for opening accounts in microfinance. It indicates that non-multiple clients are engaged in saving for future funds requirement to expand the business.

Multi financing cases have become a serious issue in the Nepalese MF industry due to restraining MF services in densely populated areas. Among the multiple borrowing clients, some of them have taken loans from various institutions and circulating this amount to pay off loans rather than be involved in productive investment. Multiple borrowing has created over-indebt to the clients due to the high amount of loans taken from various institutions beyond their capacity. Unhealthy competition among the MFIs should be discouraged in the MF sectors. MFI credit policies need to be adjusted in a manner that allows a minimum of 
overlapping. The role of the credit information bureau and regulatory authority should be effective that helps to minimize multiple borrowing. MFIs should discourage multiple borrowing practices through proper regulation, adequate supply of loans, and its productive orientation. This finding supports further to institutionalize market research, customer satisfaction monitoring, and systematic product development to the policy makers so that microfinance product become market-led.

\section{Acknowledgements}

The authors are grateful to Muktinath Bikas Bank Limited for providing research grants to conduct this research. We are thankful to both executive officers and field staff as well as all the respondents who supported and participated in this study.

\section{REFERENCES}

Ashta, A., Khan, S., \& Otto, P. (2015). Does microfinance cause or reduce suicides? Policy recommendation for reducing borrower stress. Strategic Change: Briefings in Entrepreneurial Finance, 24, 165-190.

Bateman, M. (2010). Why doesn't microfinance work? The destructive rise of local neoliberalism. London: Zed Books.

Center for Financial Inclusion. (2011). Implementing client protection in microfinance: The state of the practice, 2011. Center for Financial Inclusion at ACCION International. Retrieved from https://centerforfinancialinclusionblog.files.wordpress.com/2011/11/111108_smartcampaign_implementing-client-protection-in-microfinance-state-of-the-practice2011_final.pdf

Chen, G., Rasmussen, S., \& Reille, X. (2010). Growth and vulnerabilities in microfinance. Washington, DC: Consultative Group to Assist the Poor (CGAP).

Debnath, K., \& Roy, P. (2018). Predicting multiple-borrowing default among microfinance clients. Theoretical Economics Letters, 8, 1772-1792. Retrieved from https://doi.org/10. 4236/tel.2018.810116

Dhungana, B. R., Singh, J. K., Acharya, D., Gautam, S., \& Paudyal, P. (2016). Perceived usefulness of a microfinance intervention on health awareness and practices in Nepal. Front Public Health. Retrieved from 10.3389/fpubh.2015.00289

Faruqee, R., \& Khalily, B. (2011). Multiple borrowing by MFI clients: Current status and implications for future of microfinance. Policy Paper. Institute of Microfinance, Dhaka, Bangladesh.

Godden, B. (2004). Sample size formula. Journal of Statistics. Retrieved from http://williamgoddencom/samplesizeformula.pdf 
Islam, M. S. (2019). Multiple borrowing and living standards: A study in Bangladesh. International Journal of Economic Behavior and Organization,7(1), 19-27. doi: 10.11648/j.ijebo.20190701

Krishnaswamy, K. (2007). Competition and multiple borrowing in the Indian microfinance sector. Center for Microfinance, IFMR, Chennai. Working Paper.

Lahkar, R., \& Pingali, V. (2014). Risk diversification through multiple group membership in microfinance. Applied Economics Letters, 21(9), 622-625.

Ledgerwood, J. (1999). Microfinance handbook: An institutional and financial perspective. Washington, DC: The World Bank.

Levin, G. (2012). Critique of microcredit as a development model. Pursuit - The Journal of Undergraduate Research at the University of Tennessee, 4(1), 109-117. Retrieved from http://trace.tennessee.edu/pursuit/vol4/iss1/9

Lutzenkirchen, C., \& Weistroffer, C. (2012). Microfinance in evolution: An industry between crisis and advancement. Deutsche Bank Research, Berlin.

Maurer, K., \& Pytkowska, J. (2010). Indebtedness of microcredit clients in Bosnia and Herzegovina: Results from a comprehensive field study. European Fund for Southeast Europe.

Microfinance Focus. (2011, April 22). Microfinance crises that the sector does not want to remember. Retrieved from http://www.microfinancefocus.com/6-microfinancecrises-sector-does-not-want-remember

Mpogole, H., Mdaungulu, I., Mlasu, S., \& Lubawa, G. (2012). Multiple borrowing and loan repayment: A study of microfinance clients at Iringa, Tanzania. Global Journal of Business and Management Research, 12(4), 97-102.

Roodman, D. (2012). Due diligence: An impertinent inquiry into microfinance. Washington, DC: Center for Global Development.

Schicks, J. (2014). Over-indebtedness in microfinance - an empirical analysis of related factors on the borrower level. World Development, 54, 301-324.

Swope, T. (2010). Microfinance and poverty alleviation. Rollins Undergraduate Research Journal, 2 (1), 134-142.

Tilakaratna, G., \& Hulme, D. (2015). Microfinance and multiple borrowing in Sri Lanka: Another microcredit bubble in South Asia? South Asia Economic Journal,16(1), 4663. doi: 10.1177/1391561415575127http://sae.sagepub.com

The World Bank. (2017). Global financial development report. Washington DC: The World Bank. 